\title{
PEMBUATAN SEDIAAN PARAM ANTIPANU RIMPANG LENGKUAS MERAH (Alpinia purpurata K.Schum) DARI BERAS (Oriza sativa L) SEBAGAI BAHAN PENGISI
}

\author{
Tiwi Pratiwi', Risa Kota Putra ${ }^{2 *}$, Yusi Helmiawati ${ }^{3}$ \\ 1,2,3 Sekolah Tinggi Ilmu Kesehatan Holistik \\ *Korespondensi: Jl. Veteran No.272 Ciseureuh Purwakarta, Email: risakotaputra@yahoo.co.id
}

\begin{abstract}
ABSTRAK
Latar Belakang: Lengkuas merah (Alpinia purpurata K.Schum) merupakan salah satu tumbuhan yang sudah dimanfaatkan khasiatnya secara turun-temurun oleh masyarakat di Desa Tanggulun Barat RT.23/RW.06 Kecamatan Kalijati Kabupaten Subang, sebagai suatu swamedikasi penyakit panu. Namun, semakin berkembangnya teknologi di bidang pengobatan sebagian besar masyarakat cenderung memilih obat sintetis daripada obat herbal, khususnya masyarakat di perkotaan.
\end{abstract}

Tujuan Penelitian: Penelitian ini bertujuan untuk membuat sediaan param antipanu rimpang lengkuas merah (Alpinia purpurata K.Schum) dari beras (Oryza sativa L) sebagai bahan pengisi yang stabil secara organoleptis.

Metode: Desain yang digunakan pada penelitian ini adalah etnofarmakologi. Penelitian diawali dengan pengumpulan data melalui wawancara kepada masyarakat di desa Tanggulun Barat RT.23/RW.06 Kalijati kabupaten Subang yang menjadi acuan pembuatan sediaan param dengan variabel lama waktu penjemuran dengan maksud untuk mengetahui pengaruh kadar air terhadap stabilitas sediaan selama dalam penyimpanan. Pengujian stabilitas sediaan param dilakukan dengan pengamatan organoleptis dalam tiga variabel penyimpanan.

Hasil: Hasil menunjukan bahwa sediaan param yang dijemur selama satu hari memiliki stabilitas warna dan aroma yang lebih baik dibandingkan penjemuran dua dan tiga hari, sedangkan hasil pengujian organoleptik sediaan menunjukan tidak ditemukannya perbedaan stabilitas bentuk dan pertumbuhan jamur pada semua sampel, namun terjadi perubahan aroma dan warna pada penyimpanan dalam wadah terbuka dan tertutup dengan silica gel.

Simpulan: Simpulan dari penelitian ini adalah sediaan param dengan penjemuran satu hari dengan penyimpanan dalam wadah tertutup tanpa silica gel memberikan hasil dan stabilitas yang baik selama tiga minggu.

Kata kunci: lengkuas merah, param, uji organoleptik

\begin{abstract}
Background: The red galangal (Alpinia purpurata K.Schum) is one of the plants that has been known for its benefits by the people of Tanggulun Barat village RT.23/RW.06 Kalijati, Subang Regency, as swamedication to prevent and treat ringworm. However, medical thecnology developed for the majority of people tends to be synthetically made and does not have any herb characteristics at all, especially in the urban society.

Objective: This research aims to produce Red Galangal Rhizomes (Alpinia purpurata K.Schum) anti-ringworm param supply from rice (Oriza sativa L) as stable filler organoleptically.

Method: Etnofarmacology was used as a design in this research. This research begins with the accumulation of data through interview with the people of Tanggulun Barat village RT.23/RW. 06 Kalijati, Subang Regency which become the reference to produce param supply with variable time length of drying in the sunlight in the purpose to find out the effect of water content towards the stability of supply throughout storaging process. Param supply stability testing done by organoleptic observation in three storage variable.

Result: Result shows that param supply which was dried in the sunlight for one day had a better color and aroma stability compared to two and three days of drying, while the organoleptic testing of supply results in the difference of form and fungus growth to be not found on all samples, however there have been changes on aroma and color on storage inside open and closed container with the silica gel.
\end{abstract}


Conclusion: The conclusion of this research is that the param supply with the process of drying in the sunlight for one day with closed container storage without silica gel gives fine product and stability which can withstand up to three weeks.

Keywords: red galangal, param, organoleptic test

\section{PENDAHULUAN}

Di negara beriklim tropis seperti Indonesia dengan kelembaban dan suhu yang cukup panas menyebabkan kemungkinan meningkatnya perkembangan infeksi yang disebabkan oleh jamur. Menjaga kebersihan kulit badan menjadi salah satu faktor penting dalam pencegahan timbulnya beberapa penyakit kulit yang mudah menular, salah satunya yaitu panu. ${ }^{1}$ Panu (Pityriasis versicolor) merupakan penyakit infeksi jamur pada kulit yang disebabkan oleh Malassezia furfur. ${ }^{2}$ Panu termasuk penyakit kulit menular yang ditandai dengan adanya bercak pada kulit disertai rasa gatal terutama apabila terkena keringat.

Lengkuas merah (Alpinia purpurata K.Schum) merupakan salah satu tumbuhan yang sudah dimanfaatkan khasiatnya secara turun-temurun oleh masyarakat di Desa Tanggulun Barat RT.23/RW.06 Kecamatan Kalijati Kabupaten Subang, sebagai salah suatu swamedikasi penyakit panu. Bagian yang digunakannya adalah rimpangnya dengan cara pemakaian digosokkan langsung ke permukaan kulit yang terkena panu atau diparut terlebih dahulu baru dibalurkan kebagian panu.

Beberapa penelitian menunjukkan bahwa lengkuas memiliki khasiat sebagai antijamur. Salah satu hasil penelitian menyatakan bahwa adanya perbedaan yang signifikan dalam menghambat pertumbuhan jamur Candida albicans secara in vitro pada ekstrak lengkuas merah dan ekstrak lengkuas putih. Perbedaan tersebut ditandai dengan rerata luas diameter pada daya hambat jamur Candida albicans dalam cawan petri terhadap ekstrak lengkuas merah sebesar 6,33 mm sedangkan pada ekstrak lengkuas putih sebesar 5,00 mm. ${ }^{3}$

Namun, semakin berkembangnya teknologi di bidang pengobatan sebagian besar masyarakat cenderung memilih obat sintetis daripada obat herbal, khususnya masyarakat di perkotaan. Kecenderungan ini dapat didasari pada penggunaan obat sintetis yang lebih praktis pemakaiannya dan reaksi obatnya lebih cepat dibandingkan obat herbal. ${ }^{4}$ Akan tetapi, penggunaan obat sintetis secara terusmenerus dapat memberikan efek yang kurang baik bagi tubuh. ${ }^{5}$ Oleh sebab itu, perlu dikembangkan pengobatan herbal yang penggunaannya lebih praktis dan bisa dibawa berpergian jauh.

Berdasarkan penelitian yang telah dilakukan sebelumnya, diketahui bahwa beberapa bentuk sediaan dari bahan lengkuas merah yang sudah diteliti sebagai antijamur adalah sediaan salep dan sampo. Sedangkan penelitian dalam bentuk sediaan param belum ada yang melakukannya. Maka dari itu, peneliti berkeinginan untuk membuat sediaan param antipanu rimpang lengkuas merah dari beras sebagai bahan pengisi sehingga mempermudah masyarakat dalam mengatasi keluhan panu, praktis penggunaannya, dan bisa dibawa berpergian jauh.

\section{METODE PENELITIAN}

Lokasi penelitian dilakukan di Desa Tanggulun Barat RT. 23/RW.06 Kecamatan Kalijati Kabupaten Subang dengan waktu selama satu bulan yaitu dari tanggal 1 Agustus 2017 - 31 Agustus 2017. Partisipan penelitian merupakan masyarakat setempat sebanyak 10 orang dengan rentan usia 4065 tahun.

Desain yang digunakan pada penelitian ini adalah etnofarmakologi. Etnofarmakologi merupakan bagian dari etnobotani (ilmu botani) yang mempelajari khusus tentang kegunaan tumbuhan yang memiliki efek farmakologi untuk pengobatan dan pemeliharaan kesehatan dalam suatu kultur budaya masyarakat. ${ }^{6}$

Pembuatan sediaan param antipanu dilakukan dengan cara menghaluskan rimpang lengkuas merah (Alpinia purpurata K.Schum) sebanyak 100 gram (untuk satu kelompok) yang sebelumnya sudah dibersihkan terlebih dahulu. Haluskan juga 
beras sebanyak 200 gram (untuk satu kelompok) yang sebelumnya sudah direndam selama dua jam. Kedua bahan dicampur menjadi homogen lalu dibentuk menjadi bulatan pipih sebanyak 30 butir. Setelah selesai pembuatan sediaan param sebanyak tiga kelompok, jemur sediaan param dengan frekuensi waktu yang berbeda. Kelompok A dijemur selama satu hari, kelompok B dijemur selama dua hari, dan kelompok C dijemur selama tiga hari.

Sediaan param yang sudah dijemur dibagi menjadi tiga sampel penyimpanan setiap kelompoknya, yaitu sampel-1 disimpan dalam wadah terbuka, sampel-2 disimpan dalam wadah tertutup, dan sampel-3 disimpan dalam wadah tertutup dengan silica gel. Pengujian organoleptik sediaan param dilakukan selama tiga minggu dengan mengamati bentuk, aroma, warna, dan pertumbuhan jamur yang dicatat setiap satu minggu sekali.

\section{HASIL PENELITIAN \\ Hasil Wawancara}

Wawancara dilakukan pada tanggal 67 Agustus 2017 terhadap masyarakat Desa Tanggulun Barat RT.23/RW.06 Kecamatan
Kalijati, Kabupaten Subang dengan jumlah partisipan sebanyak 10 orang.

Hasil wawancara didapatkan data yang menyatakan adanya kebenaran mengenai penggunaan lengkuas merah sebagai antipanu secara turun-temurun. Sebanyak 10 partisipan juga mengatakan pemakaiannya bisa menggunakan rimpang lengkuas merah yang masih muda atau lengkuas merah yang sudah tua dengan cara digosok atau diparut terlebih dahulu. Dalam penggunaannya, sebanyak dua orang mengatakan pernah mengkombinasikannya dengan belerang, satu orang partisipan pernah mengkombinasikan dengan kapur sirih, dan satu orang partisipan lainnya pernah mengkombinasikannya dengan minyak kelapa. Akan tetapi dalam pemakaiannya, hanya ada empat orang yang menggunakannya secara rutin jika terkena panu, dan sebagian lainnya lebih menggunakan obat sintetis.

Adapun keluhan masyarakat dalam penggunaan rimpang lengkuas merah secara langsung sebagai pengobatan tradisional. Beberapa keluhan tersebut dapat dilihat pada tabel 1.

Tabel 1 Alasan Partisipan Tidak Menggunakan Lengkuas Merah Sebagai Antipanu

\begin{tabular}{|c|c|}
\hline Keluhan & Partisipan \\
\hline Malas mengolahnya & 2 \\
\hline Repot membuatnya & 1 \\
\hline Prosesnya lambat & 3 \\
\hline
\end{tabular}

Berdasarkan tabel 1 diketahui bahwa dari 10 partisipan yang diwawancarai dua orang menyatakan malas mengolahnya, satu orang menyatakan repot dalam membuatnya, dan tiga orang menyatakan prosesnya lambat.

\section{Hasil Pembuatan Sediaan}

Hasil pembuatan sediaan param yang dilakukan dengan cara menghomogenkan 100 gram rimpang lengkuas merah yang sudah dihaluskan dengan 200 gram tepung beras menghasilkan sebanyak 30 keping param dengan rata-rata berat satu param adalah 10 gram. Hasil sediaan dapat dilihat pada tabel 2 .

Tabel 2. Sediaan Param Sebelum Penjemuran

\begin{tabular}{|c|c|c|}
\hline Gambar & & Keterangan \\
\hline & $\begin{array}{l}\text { Bentuk } \\
\text { Warna } \\
\text { Aroma } \\
\text { Jamur }\end{array}$ & $\begin{array}{ll}: & \text { Bulat pipih } \\
: & \text { Putih } \\
: & \text { Khas rimpang lengkuas merah } \\
: & \text { Tidak ada }\end{array}$ \\
\hline
\end{tabular}


Sediaan param yang masih basah kemudian dijemur dengan penjemuran langsung sinar matahari dengan tempo waktu yang berbeda tiap kelompoknya, yaitu kelompok A dijemur selama satu hari, kelompok B dijemur selama dua hari, dan kelompok $\mathrm{C}$ dijemur selama tiga hari.

Hasil penjemuran sediaan param menunjukkan adanya perubahan terhadap warna sediaan. Pada kelompok A warna sediaan menjadi putih kekuningan, kelompok B warna sediaan menjadi putih agak kecokelatan, dan kelompok C warna sediaan menjadi putih kecokelatan. Ketiga kelompok ini kemudian dibagi menjadi tiga sampel cara penyimpanan yang berbeda untuk diamati organoleptiknya.

\section{Hasil Pengamatan Organoleptik}

Pengamatan organoleptik sediaan param rimpang lengkuas merah mencangkup bentuk sediaan, warna, aroma, dan pertumbuhan jamur. Dari hasil pengamatan yang dilakukan selama tiga minggu terhadap masing-masing sampel sediaan, didapatkan adanya perubahan yang signifikan pada aroma sediaan selama proses penyimpanan dengan perlakuan yang berbeda.

Pada sampel-1 dengan penyimpanan wadah terbuka menunjukkan aroma lengkuas merah yang terus berkurang setiap minggunya, pada sampel-2 dengan penyimpanan wadah tertutup menunjukkan aroma lengkuas merah yang tetap terjaga setiap minggunya, dan pada sampel-3 dengan penyimpanan wadah tertutup dengn silica gel menunjukkan aroma lengkuas merah yang tetap terjaga, akan tetapi pada minggu ketiga aromanya mulai berkurang.

Hasil pengamatan dari ketiga kelompok dengan masing-masing sampel penyimpanan yang berbeda, didapatkan hasil yang stabil pada kelompok A sampel-2 dengan tidak adanya perubahan bentuk, warna tidak terlalu gelap, aroma khas rimpang lengkuas merah tetap terjaga, dan tidak adanya pertumbuhan jamur pada sediaan param. Hasil sediaan dapat dilihat pada tabel 3.

Tabel 3. Sediaan Param Rimpang Lengkuas Merah Kelompok A (Penjemuran Satu Hari) Sampel-2 (Penyimpanan Wadah Tertutup)

\begin{tabular}{|c|c|c|}
\hline Gambar & & Keterangan \\
\hline & $\begin{array}{l}\text { Bentuk } \\
\text { Warna } \\
\text { Aroma } \\
\text { Jamur }\end{array}$ & $\begin{array}{ll}: & \text { Bulat pipih } \\
: & \text { Putih Kekuningan } \\
: & \text { Khas rimpang lengkuas merah } \\
: & \text { Tidak ada }\end{array}$ \\
\hline
\end{tabular}

\section{PEMBAHASAN}

Berdasarkan hasil wanwancara terhadap 10 partisipan di Desa Tanggulun Barat RT.23/RW.06 Kecamatan Kalijati, Kabupaten Subang diketahui penggunaan rimpang lengkuas merah dapat dikombinasikan menggunakan belerang atau pun kapur sirih, hal ini dilakukan untuk membantu proses penyembuhan lebih cepat. Akan tetapi efek dari kombinasi bahan tersebut menyebabkan rasa yang panas di kulit. Adapun kombinasi lengkuas dengan minyak kelapa yang bisa digunakan untuk anak kecil karena dapat mengurangi efek panas pada kulit yang ditimbulkan oleh lengkuas merah.

Perlakuan penjemuran sediaan param yang berbeda menghasilkan pengaruh yang berbeda terhadap warna dan bau dari sediaan param. Berdasarkan hasil penelitian yang didapat, semakin lama proses penjemuran sediaan param maka warna sediaan akan semakin memudar dan aroma yang terdapat pada sediaan semakin berkurang. Hal ini dapat diperkirakan dari menguapnya kandungan minyak atsiri dalam lengkuas merah yang berkaitan dengan warna dan aroma. Selain itu, karena sifat penjemurannya yang langsung terkena 
sinar matahari tanpa penutup menyebabkan adanya debu yang menempel pada permukaan sediaan yang masih basah sehingga menyebabkan warna menjadi lebih gelap.

Berdasarkan hasil pengamatan sediaan param yang penulis buat selama pengujian tiga minggu, menunjukkan bahwa tidak adanya perbedaan terhadap kestabilan bentuk dan pertumbuhan jamur. Hasil pengamatan lain ditemukan adanya perbedaan yang signifikan pada perubahan aroma sediaan param yaitu penurunan aroma selama penyimpanan sediaan param dalam wadah terbuka dan dalam wadah tertutup dengan silica gel.

Menurut analisa peneliti hilangnya aroma pada penyimpanan terbuka dipengaruhi oleh udara dan suhu sekitar, sedangkan penurunan aroma yang disimpan dalam tempat tertutup dengan silica gel dikarenakan adanya absorbsi oleh silica gel tersebut. Akan tetapi pada sediaan dalam wadah tertutup aroma khas tertahan sehingga tetap stabil selama pengujian tiga minggu.

Terjadinya peristiwa berkurangnya aroma pada kedua perlakuan tersebut sangat beralasan, karena aroma dari sediaan param lengkuas merah berasal dari kandungan minyak atsiri. Oleh sebab itu, berdasarkan hasil penyimpanan sediaan param menunjukan bahwa cara penyimpanan sediaan param dalam wadah tertutup menghasilkan stabilitas yang lebih baik daripada penyimpanan dalam wadah terbuka ataupun tertutup dengan silica gel.

\section{SIMPULAN}

Dari hasil penelitian yang telah dilakukan dapat disimpulkan bahwa secara empiris lengkuas merah memang benar sudah dimanfaatkan khasiatnya sebagai antipanu oleh masyarakat di Desa Tanggulun Barat RT.23/RW.06 Kecamatan Kalijati Kabupaten Subang.

Stabilitas sediaan param yang paling baik adalah kelompok A dengan sampel-2 yaitu sediaan dengan penjemuran sehari dengan cara penyimpanan dalam wadah tertutup tanpa silica gel. Hal tersebut dapat dilihat dari bentuk sediaannya yang stabil, warnanya yang tidak terlalu gelap, aroma khasnya yang stabil serta tidak ditemukannya jamur pada permukaan sediaan param selama masa penyimpanan tiga minggu.

\section{DAFTAR PUSTAKA}

1. Hayati, Inayah., dan Zivensi Putri Handayani, (2014), Identifikasi Jamur Malassezia Furfur Pada Nelayan Penderita Penyakit Kulit Di RT 09 Kelurahan Malabro Kota Bengkulu, Bengkulu: Jurnal Gradien Vol. 10: 972975.

2. Djuanda, Prof. Dr. dr. Adhi dkk., (2007), Ilmu Penyakit Kulit dan Kelamin, Jakarta: Universitas Indonesia.

3. Naldi, Yandri \& Icka Siti Aisah, (2014), Perbandingan Efektivitas Lengkuas Merah (Alpinia Purpurata K Schum) dan Lengkuas Putih (Alpinia Galanga) Terhadap Pertumbuhan Jamur Candida Albicans Secara In Vitro, Jurnal Vol 1, No 4: Tunas Medika Jurnal Kedokteran \& Kesehatan.

4. Pangastuti, R.M., (2014), Hubungan Pengetahuan dan Sikap Mengenai Obat Tradisional dan Obat Modern dengan Tindakan Pemilihan Obat untuk Pengobatan Mandiri di Kalangan Masyarakat Desa Bantir, Kecamatan Candiroto, Kabupaten Temanggung, Jawa Tengah, skripsi, Fakultas Farmasi, Universitras Sanata Dharma, Yogyakarta, Indonesia.

5. Ismarani, (2013), Kajian Persepsi Konsumen Terhadap Penggunaan Obat Herbal (Kasus Di Unisma Bekasi, Cefars: Jurnal Agribisnis dan Pengembangan Wilayah Vol. 4 No. 2 Juni 2013.

6. Agustian, Pitria., (2014), Leksikon Etnofarmakologi Di Kampung Adat Ciptagelar, Desa Sirnaresmi, Kecamatan Cisolok, Kabupaten Sukabumi (Kajian Etnolinguistik, Skripsi, Universitas Pendidikan Indonesia. 